\title{
$\mathrm{U}-\mathrm{Pb}$ and $\mathrm{Lu}-\mathrm{Hf}$ systematics of zircons from Sargur metasediments, Dharwar Craton, Southern India: new insights on the provenance and crustal evolution
}

\author{
Bidyananda Maibam ${ }^{1, *}$, Axel Gerdes ${ }^{2}$, R. Srinivasan ${ }^{3}$ and J. N. Goswami ${ }^{4}$ \\ ${ }^{1}$ Department of Earth Sciences, Manipur University, Imphal 795 003, India \\ ${ }^{2}$ Institute of Geosciences, Mineralogy, J.W. Goethe University, Frankfurt 60438, Germany \\ ${ }^{3}$ Centre for Atmospheric and Ocean Sciences, Indian Institute of Science, Bengaluru 560 012, India \\ ${ }^{4}$ Physical Research Laboratory, Navrangpura, Ahmedabad 380 009, India
}

\begin{abstract}
A study of $\mathrm{U}-\mathrm{Pb}$ and $\mathrm{Lu}-\mathrm{Hf}-\mathrm{Yb}$ isotope data in zircons from metamorphosed psammopelite and quartzite from the type area of Archaean Sargur Group, Dharwar Craton, India is carried out. Two age populations are observed: an older population with concordant $\mathrm{U}-\mathrm{Pb}$ ages between 2.7 and $2.8 \mathrm{Ga}$, and a younger population with ages in the $2.4-2.6 \mathrm{Ga}$ age range. The $\varepsilon \mathrm{Hf}$ values of 0 to $+\mathbf{2 . 0}$ for the older zircon population suggest that they were derived from juvenile crust formed at $2.7-2.8 \mathrm{Ga}$. Sub-chondritic $\boldsymbol{\varepsilon} \mathbf{H f}$ values for the younger population indicate metamorphism and/or crustal reworking at $\sim 2.5 \mathrm{Ga}$. Metasedimentary enclaves in the Sargur type area are therefore part of the gneiss-supracrustal complex of different antiquities and may not have an independent stratigraphic status.
\end{abstract}

Keywords: Detrital zircon, high- and low-grade metamorphism, isotope analysis, supracrustal rocks.

IN the amphibolite to granulite facies high-grade metamorphic gneiss-granulite terrains of the Archaean cratons, metasedimentary and metavolcanic rocks typically occur as meso- to macro-scale enclaves in gneisses and granulites. Whether these enclaves of supracrustal rocks are remnants of the rock formations of greenstone belts in the deeper sections of the earth's crust, or they belong to a stratigraphic sequence older/younger than the ones preserved in the greenstone belts, has been a matter of debate in Archaean geology. According to Condie ${ }^{1}$, one of the popular theories is that the low and high-grade Archaean terranes represent respectively, shallow and deep levels of the same crust. Even though this view has been supported by many workers ${ }^{2-8}$, there is another proposition that the high-grade supracrustal rocks in gneiss/ granulite may have developed in a different type of tectonic setting that had different rock-formation modes,

*For correspondence. (e-mail: bmaibam@yahoo.com) prior to granite-greenstone terranes ${ }^{9}$. Shackleton ${ }^{4}$ suggested that the high-grade terranes may even be younger than the granite-greenstone terranes and may represent uplifted mobile belts that evolved between greenstone belt terranes. U-Pb detrital zircon geochronology has been pursued extensively to resolve these complex relationships $^{10-15}$. In polycyclic Archaean metamorphic assemblages, zircon grains may have grown during different geological processes and/or may have been affected by multiple alteration processes ${ }^{16,17}$. Combined $\mathrm{U}-\mathrm{Pb}$ and $\mathrm{Lu}-\mathrm{Hf}$ zircon datasets can provide new insights on the timing of primary and secondary events such as juvenile versus crustal remelting, magma sources or metamorphism $^{18,19}$. The isotope data can also provide tight constraints on the timing of crustal growth and reworking ${ }^{16}$.

In the Dharwar Craton, Archaean high-grade metamorphic rocks of the Sargur Group have been suggested to be older than the low-grade greenschist facies metamorphic rocks of the Dharwar greenstone belts - the Dharwar Supergroup $^{20}$. In this study, we have performed in situ $\mathrm{U}-\mathrm{Pb}$ and $\mathrm{Lu}-\mathrm{Hf}$ isotopic analysis of zircons by laser ablation inductively coupled plasma mass spectrometer (LA-ICP-MS) to understand the ages of zircons in two metasedimentary enclaves from the type area of the Sargur Group, to infer the age of the juvenile and/or reworking/metamorphic history of the zircons. Implication of our findings for the lithostratigraphic division of the Archaean rocks in the Dharwar Craton into Sargur Group and Dharwar Supergroup is discussed.

In the Dharwar Craton of southern India, the Meso- to Neoarchaean lithostratigraphic sequence has been divided into the Sargur Group and the Dharwar Supergroup ${ }^{20}$. The Sargur Group has been considered by several workers as the oldest group in the Archaean sequence of the Dharwar Craton ${ }^{21}$; it is assigned to an age older than $3 \mathrm{Ga}$. The rocks of the Dharwar Supergroup, constituting the well-defined Dharwar greenstone belts (also referred to by different workers as schist belts or supracrustal 
belts) are considered to be younger and deposited between 3 and $2.55 \mathrm{Ga}$. On the basis of the first $\mathrm{U}-\mathrm{Pb}$ SHRIMP zircon age data for the detrital zircons, separated from the quartzites of the Sargur Group exposed near Holenarasipur and Banavar, Nutman et al. ${ }^{11}$ suggested that the sedimentary protoliths of quartzites were derived from a provenance with a minimum age of $3.0 \mathrm{Ga}$. Jayananda et al. ${ }^{22}$ and Maya et al. ${ }^{23}$ reported 3.35 and $3.15 \mathrm{Ga}$ ages respectively, for the komatiitic ultramafic rocks of the Sargur Group. Trendall et al. ${ }^{24}$ reported $\mathrm{U}-\mathrm{Pb}$ SHRIMP zircon ages of 2.72 and 2.6 Ga for the metavolcanic rocks of the Bababudan and Chitradurga Groups respectively, of the Dharwar Supergroup. SHRIMP U-Pb geochronological studies of the felsic volcanic rocks have largely reinforced the view that the Dharwar greenstone belt volcanics are younger than $3 \mathrm{Ga}$ (refs 25-27). Although the foregoing geochronological studies support the classification of supracrustal sequence in the Dharwar Craton into Sargur Group (older than $3.0 \mathrm{Ga})$ and Dharwar Supergroup (3.0-2.55 Ga), they contradict an alternative view that the Sargur Group rocks, which occur as enclaves in gneisses, are a complex that consists of supracrustal rocks of Dharwar Supergroup as well as of some older rocks ${ }^{8,28}$. Except for a recent attempt by Lancaster et al. $^{29}$, no combined $\mathrm{U}-\mathrm{Pb}$ and $\mathrm{Lu}-\mathrm{Hf}$ geochronological study of zircons from the metasediments of the type area of Sargur Group has been carried out to support either of these alternative points of view. The study of one quartzite sample by Lancaster et $a l .{ }^{29}$ yielded $\mathrm{U}-\mathrm{Th}-\mathrm{Pb}$ ages consistent with the interpretation that the Sargur Group rocks are older than 3.0 Ga. The timing of upper amphibolite to granulite grade metamorphism in the Sargur area and further south has been variously proposed as $>3.0 \mathrm{Ga}$ and $\sim 2.6 \mathrm{Ga}$ (refs $30-33$ ). We note that the database for establishing a reliable age for the source rocks as well as subsequent events of metamorphism unequivocally for the metasedimentary supracrustals in the type area for the Sargur Group is still inadequate. New results on zircon $\mathrm{U}-\mathrm{Pb}$ and $\mathrm{Lu}-\mathrm{Hf}$ systematics are presented in this study for a further understanding of the minimum age of the provenance for the Sargur Group rocks, as well as the time of their postdepositional metamorphism.

\section{Geological setting of the area}

Type area for the Sargur Group is around Sargur town, which lies between the Dharwar greenstone-granite belt region in the north and gneiss-granulite region (charnockite region) in the south (Figure 1). While the rock formations in the Dharwar greenstone belts are metamorphosed under greenschist to low amphibolite facies, those of the Sargur Group are metamorphosed under upper amphibolite to lower granulite facies ${ }^{34-36}$. The metasedimentary supracrustal rocks of the Sargur Group in the type area comprise fuchsite and muscovite quartzites \pm graphite, psammopelites (kyanite/sillimanite \pm garnet \pm graphite schists), calc-silicate rocks and marbles, and banded iron formation (BIF). They are associated with metamorphosed ultramafic rocks (some with komatiite composition), and gabbro and anorthosites ${ }^{36}$. These foregoing rock formations occur as meso- to macroscale enclaves in ortho- and paragneisses (the latter sometimes contains garnet, kyanite and corundum). At some places greasy patches of charnockite and mafic granulites are observed amidst gneisses.

For this study, we have collected samples from two locations close to Sargur: (1) metamorphosed psammopelite from the hillocks near Itna $\left(12^{\circ} 01.046^{\prime}, 76^{\circ} 23.817^{\prime}\right)$ and (2) quartzite from the hill near Thumbasoge $\left(12^{\circ} 01.994^{\prime}, 76^{\circ} 23.837^{\prime}\right)$. The metamorphosed psammopelite from Itna has abundant kyanite and is associated with muscovite mica, quartz and disseminated graphite. The quartzite from Thumbasoge is an impure micaceous quartzite with flakes of graphite.

\section{Analytical methods}

The samples were crushed into centimeter-sized chips and thoroughly washed after eliminating the weathered portions. The clean chips were pulverized to $<250 \mu \mathrm{m}$ using a stainless-steel piston and cylinder. After repeated washing, non-magnetic, high-density mineral grains were

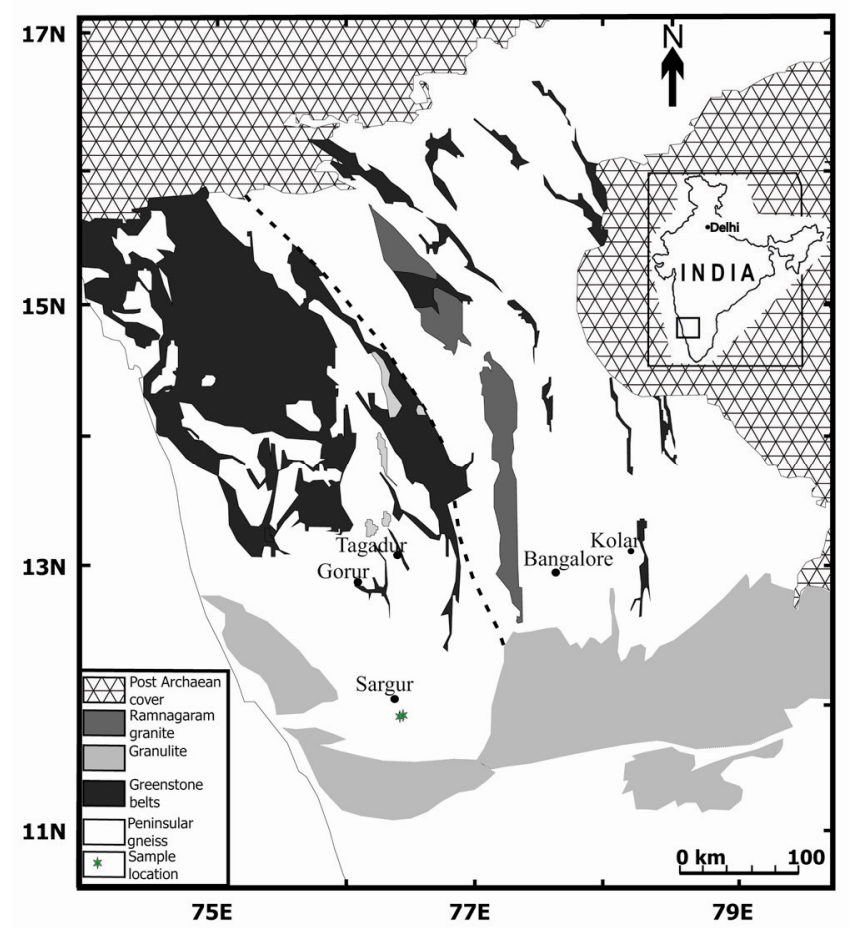

Figure 1. Geological map of the Dharwar Craton (modified from Chardon et $a l .{ }^{41}$ ). Sampling sites are marked by filled green colour. Location of some important cities and towns is also shown (circle). 


\section{RESEARCH ARTICLES}

concentrated by density separation using aqueous sodium polytungstate solution (density $=3 \mathrm{~g} \mathrm{~cm}^{-3}$ ) followed by magnetic separation using a Frantz isodynamic separator. For the kyanite-rich Itna samples, after following the standard technique, size separation was carried out at 90 , 120, 150 and $200 \mu \mathrm{m}$. Zircon grains were handpicked using a binocular microscope. They were more abundant in the $120-150 \mu \mathrm{m}$ size fractions. Clear, unfractured zircon grains were selected and mounted on a double-side adhesive tape, cast in epoxy and sectioned by polishing. Transparent zircons with simple internal structure were documented in detail. The grains recovered from the studied samples are inclusion-free, subhedral, colourless to brownish and some have metamict cores. Even though distinct overgrowths are present in a few zircons, our attempt to analyse the core-rim domains did not yield robust and reproducible age for the metamict cores. $\mathrm{U}-\mathrm{Pb}$ and $\mathrm{Lu}-\mathrm{Hf}$ isotope analysis was carried out at Goethe University, Frankfurt, Germany using a ThermoScientific Element II SF-ICP-MS and Neptune multicollector (MC)-SF-ICP-MS, both coupled to a New wave UP213 laser system. The analytical procedure adopted in this study is the same as described earlier in detail by Gerdes and $\mathrm{Zeh}^{14}$.

\section{Results}

The zircon grains analysed in the study were short as well as long prismatic and poorly sorted in size. Cathodoluminesence images of zircon grains revealed clear corerim relationships in some grains. The zircon cores show an oscillatory zoning, as is characteristic for magmatic rocks, whereas the rims show diffuse zoning pattern. Some grains show metamict cores. Figure 2 is representative back scattered electron and cathodoluminescence images of zircons.

\section{Zircon $U-P b$ isotope analysis}

$\mathrm{U}-\mathrm{Pb}$ isotope analysis was carried out on 15 zircon grains separated from the Itna psammopelite sample (Z-124; Table 1). Data for two zircon grains (A38, A39) yielded discordant $\mathrm{U}-\mathrm{Pb}$ ages (15\% discordance). These were not considered further. Two distinct concordant age populations (95-105\% concordance) were observed in the data of the other 13 grains. Four core ages (A25, A27, A29, A30) consistently yielded concordant ages in the range 2.72-2.81 Ga. Nine grains (A26, A28, A31, A32, $\mathrm{A} 40, \mathrm{~A} 41, \mathrm{~A} 43-\mathrm{A} 45)$ were in the age range 2.46 to $2.56 \mathrm{Ga}$. The weighted average age for the younger population was $2519 \pm 9 \mathrm{Ma}$. Concordance level of all the ages was $95-102 \%$ (Figure 3).

Eleven zircon grains from the Thumbasoge quartzite sample (Z-103) were analysed (Table 1). Two grains (A47 and A48) were characterized by concordant older ages of 2.66 and 2.70 Ga respectively. Rest of the nine grains gave concordant ages ranging between 2.51 and $2.53 \mathrm{Ga}$, with a weighted average age of $2521 \pm 9 \mathrm{Ma}$. The concordance level for all ages was between $95 \%$ and 101\% (Figure 3).

\section{Lu-Hf-Yb isotopic analysis}

From Itna psammopelite eight $\mathrm{Lu}-\mathrm{Hf}-\mathrm{Yb}$ isotopic analyses were conducted on the grains having enough areas for the Lu-Hf analysis (Table 2). Some of the older 2.72$2.81 \mathrm{Ga}$ zircons indicated chondritic to superchondritic nature ( $\varepsilon \mathrm{Hf}$ values $=+0.1$ to +2.0$)$ with $\mathrm{Hf}$ model ages between 2.88 and $2.99 \mathrm{Ga}$. The $\sim 2.52 \mathrm{Ga}$ younger zircons had sub-chondritic $\varepsilon \mathrm{Hf}$ values between -3.9 and -5.1 . Initial ${ }^{176} \mathrm{Hf} /{ }^{177} \mathrm{Hf}$ ratios were calculated using the $\mathrm{Lu}-\mathrm{Hf}$ isotopic data and the apparent $\mathrm{Pb}-\mathrm{Pb}$ ages were obtained from the younger zircon grains. Majority of zircon grains having different apparent $\mathrm{Pb}-\mathrm{Pb}$ ages showed similar initial ${ }^{176} \mathrm{Hf} /{ }^{177} \mathrm{Hf}$ values, indicating that the analysed younger zircon grains probably crystallized from the same source rock that yielded zircons of the older population. Identical initial ${ }^{176} \mathrm{Hf} /{ }^{177} \mathrm{Hf}$, but large variation of their corresponding ${ }^{206} \mathrm{~Pb} /{ }^{207} \mathrm{~Pb}$ ages (see Figures 4 and 5) indicated that all these grains formed at the same time; however, several zircon domains were subsequently

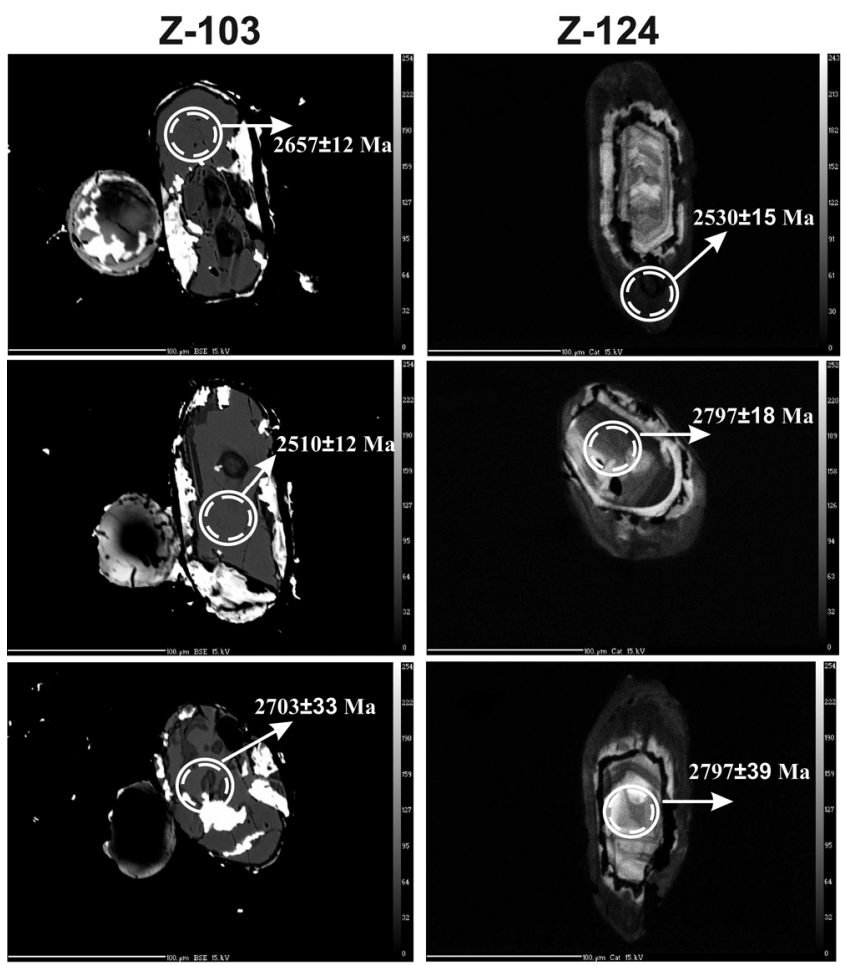

Figure 2. Representative back scattered electron (BSE) and CL images of the analysed zircons (Z-103 - Thumbasoge sample; Z-124 Itna sample). The two marked circles are analysis spots for $\mathrm{U}-\mathrm{Pb}$ (inside) and $\mathrm{Hf}$ (outside). 


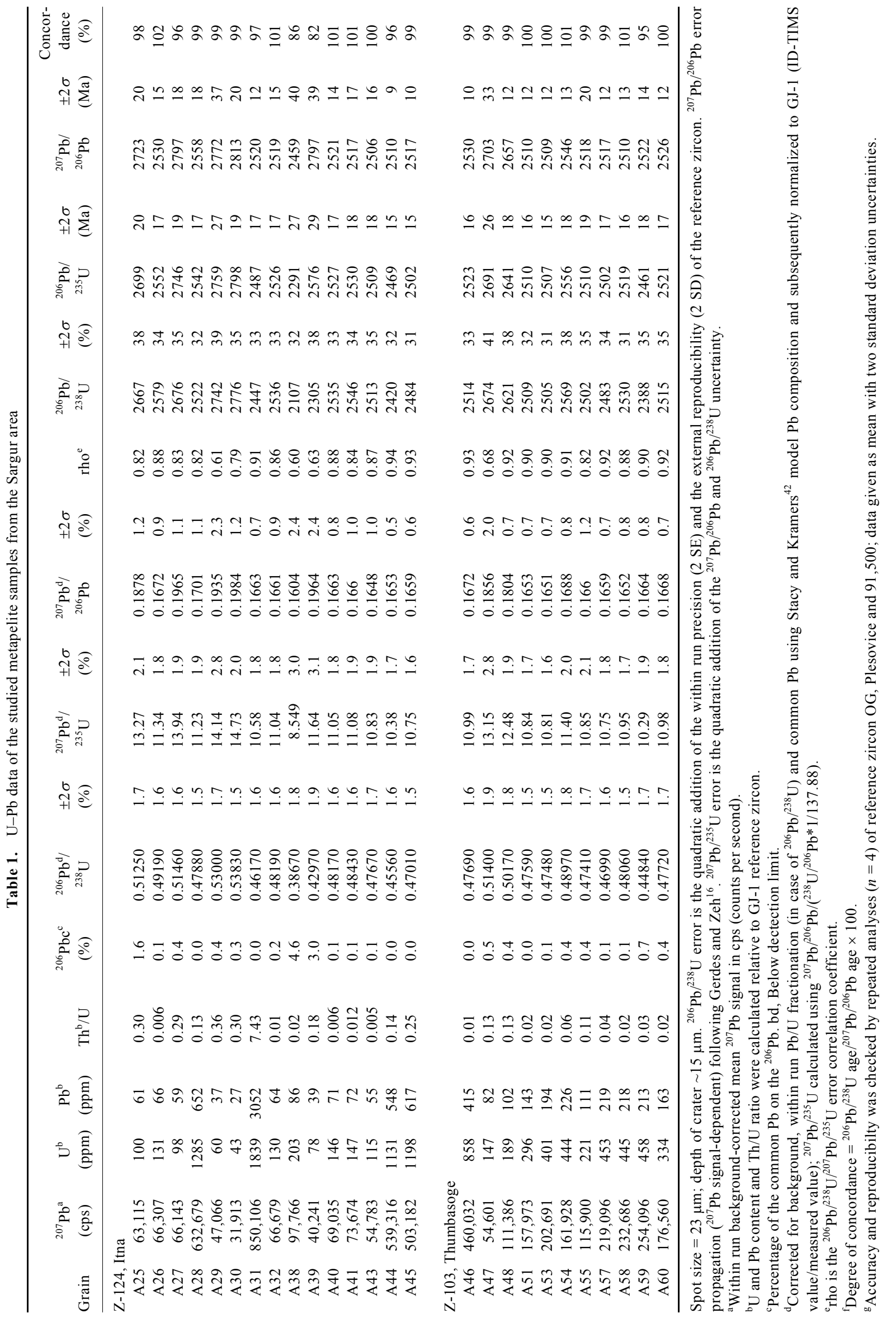




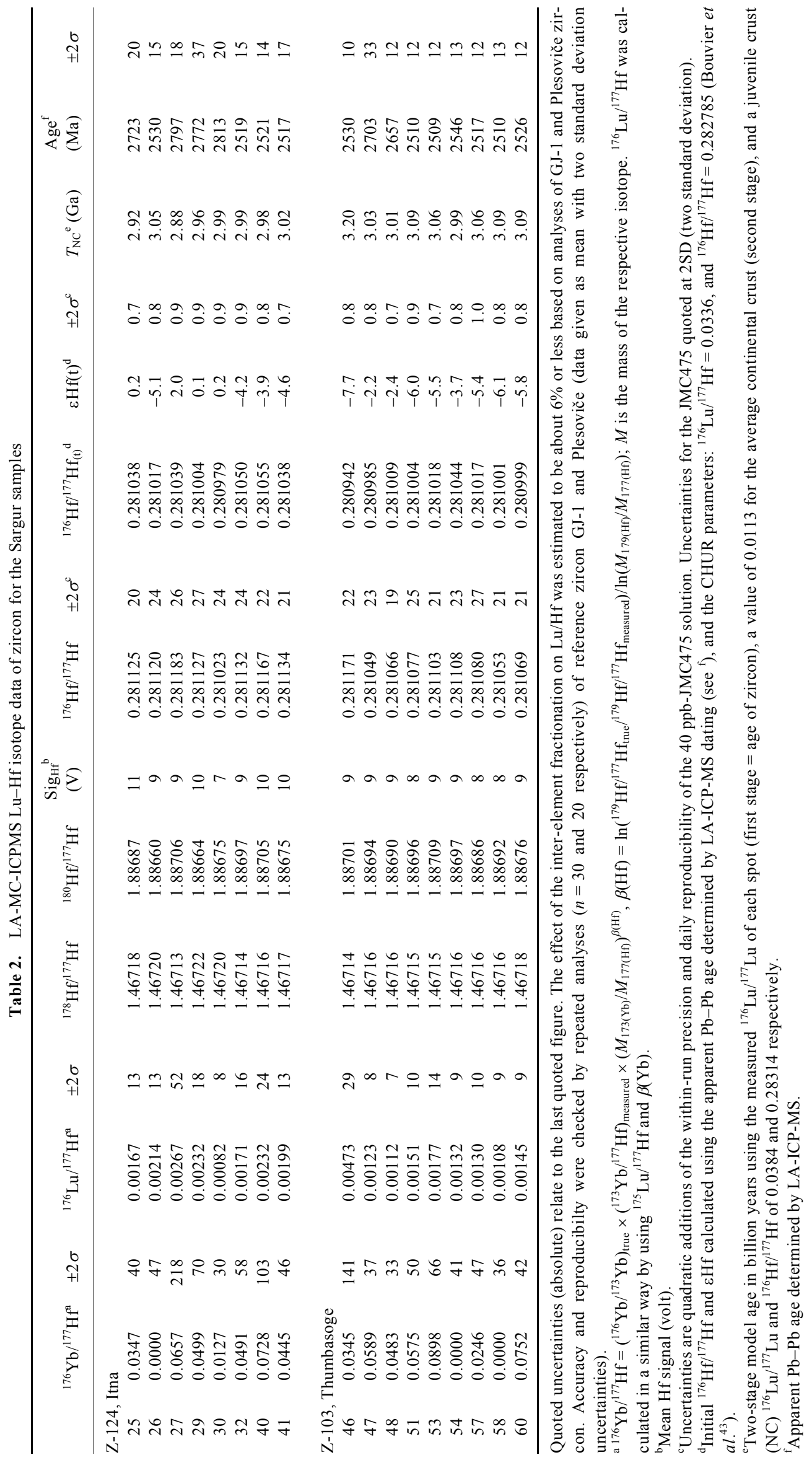


affected by multiple $\mathrm{Pb}$-loss that caused the resetting of the $\mathrm{U}-\mathrm{Pb}$ system, but left the zircon Hf isotope system unaffected (see Zeh et al. $)^{19}$. A positive correlation was seen between apparent zircon $\mathrm{Pb}-\mathrm{Pb}$ ages and $\varepsilon \mathrm{Hf}(\mathrm{t})$ (Figure 5). Model ages of the analysed grains ranged between 2.88 and $3.05 \mathrm{Ga}$. $T_{\mathrm{Hf}}^{\mathrm{DM}}$ of these zircons in the two-stage model became apparently older with decreasing apparent age. Thus, for geological interpretation, only initial Hf model ages ( $T_{\mathrm{DM}}$ initial) can be used. It may be noted that model ages also do not always correspond to 'real' continental crust formation events ${ }^{37,38}$. Zircons preserved Hf-isotope signatures from all significant sources that contributed to parental melts of these minerals. Model ages of zircons that are produced from mixed sources (e.g. melting of heterogeneous basement or mixed crust and mantle-derived source) will only show a geologically meaningless average age of all sources from which these zircons were produced. Zircon Hf model ages can be used with confidence for determining ages of crust formation when only supported by other lines of evidence, e.g. matching $\mathrm{U}-\mathrm{Pb}$ zircon age populations ${ }^{19}$.

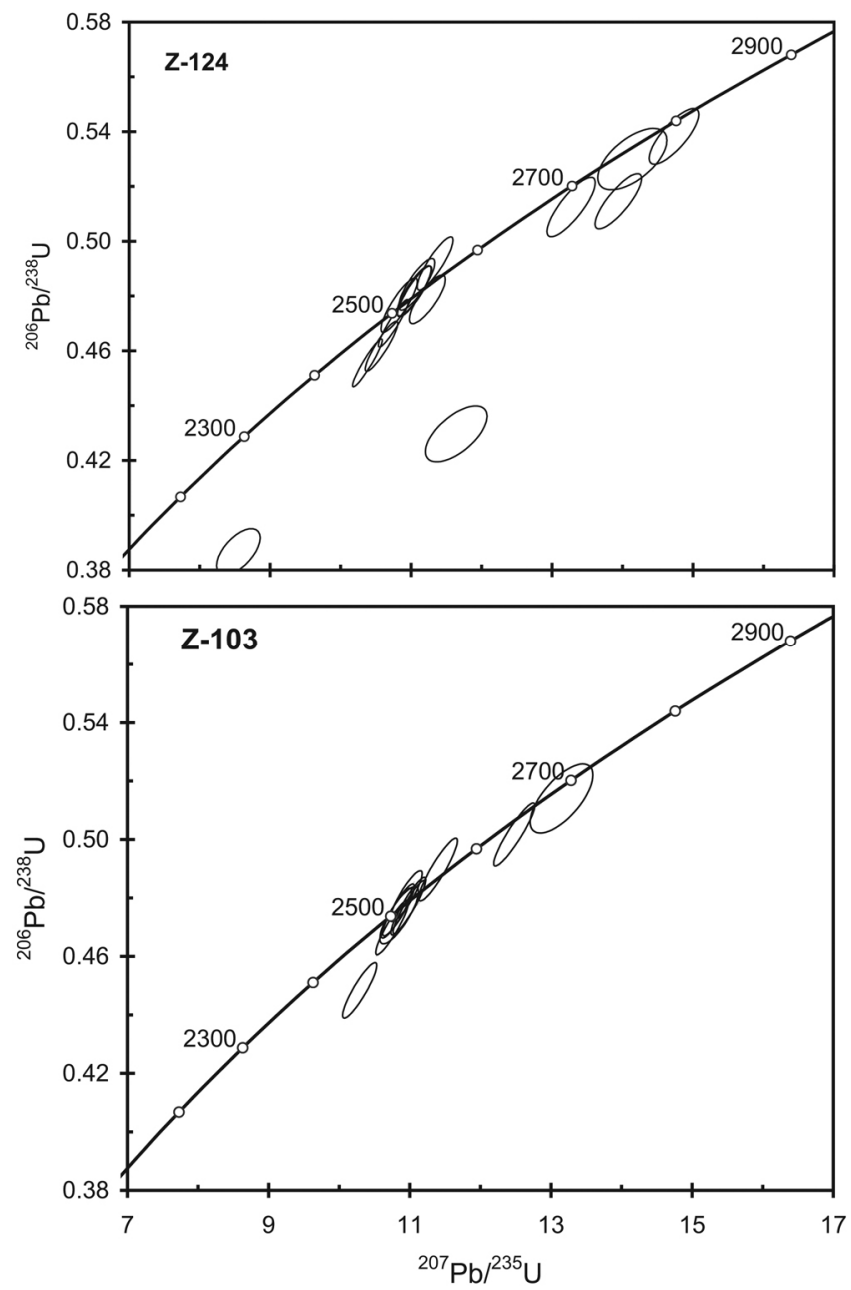

Figure 3. Concordia diagram of the studied samples.
So, we do not emphasize much on our limited zircon $\mathrm{Hf}$ model age dataset. It may be noted that zircons with core-rim morphology consistently yielded core ages of $\sim 2.8 \mathrm{Ga}$, whereas the rims were much younger, $\sim 2.5 \mathrm{Ga}$. The analyses also revealed that most of the cores yielded higher $\mathrm{Th} / \mathrm{U}(>0.2)$ than the $\mathrm{rims}(\mathrm{Th} / \mathrm{U}<0.1)$. Judging from the combined $\mathrm{CL}$ and $\mathrm{U}-\mathrm{Th}-\mathrm{Pb}$ analyses, it could be inferred that the cores are derived from magmatic source, whereas the rims formed during metamorphic overprint.

For the Thumbasoge sample Lu-Hf-Yb analyses conducted on nine grains with younger ages showed complex

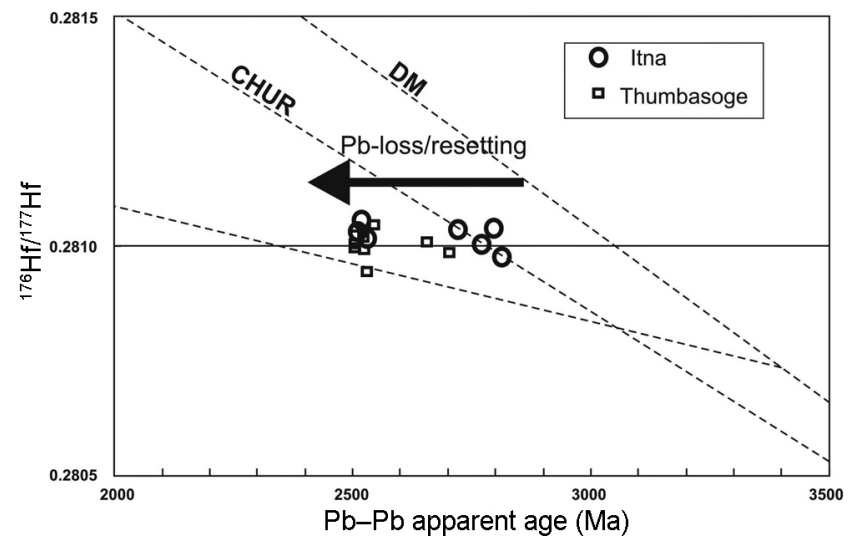

Figure 4. ${ }^{176} \mathrm{Hf} /{ }^{177} \mathrm{Hf}$ versus $\mathrm{Pb}-\mathrm{Pb}$ age plot of the studied Sargur samples with the depleted mantle and bulk earth (CHUR) reference lines.
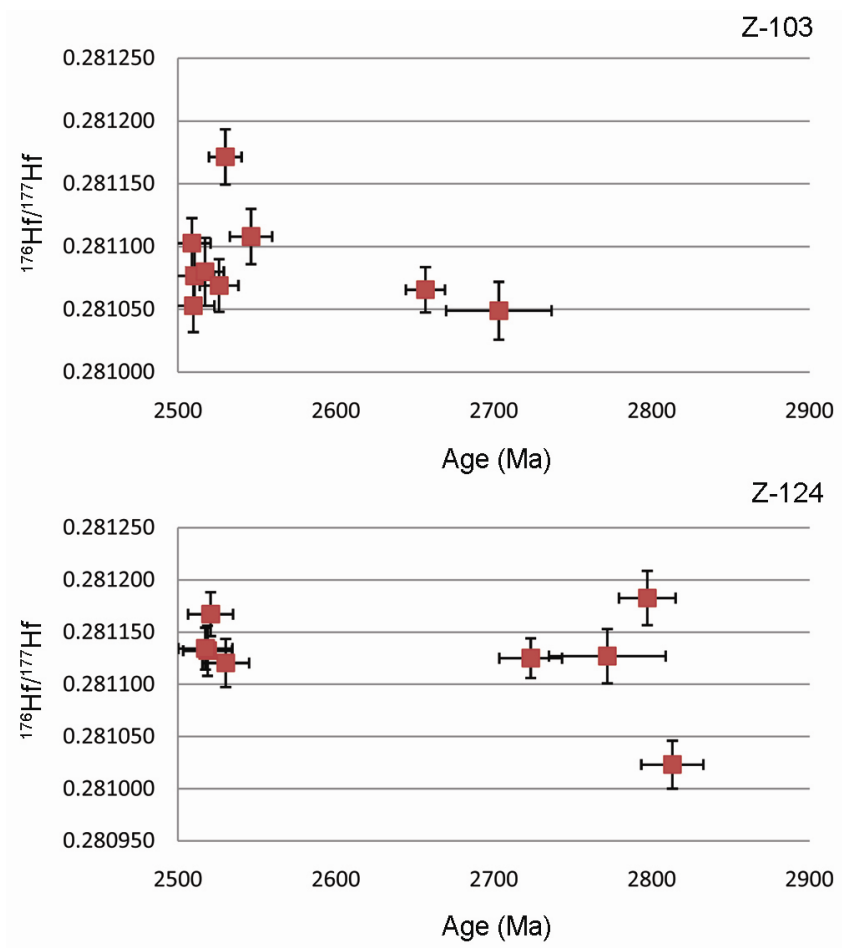

Figure 5. ${ }^{176} \mathrm{Hf} /{ }^{177} \mathrm{Hf}$ versus $\mathrm{Pb}-\mathrm{Pb}$ age plot of the studied Sargur samples. 
and significant ${ }^{176} \mathrm{Hf} /{ }^{177} \mathrm{Hf}$ and ${ }^{176} \mathrm{Yb} /{ }^{177} \mathrm{Hf}$ ratios (Table $2)$. The evolved $\mathrm{Hf}$ isotope signatures of zircons $(\varepsilon \mathrm{Hf}$ between -2.2 and -7.7 ) indicate reworking of older crust or geological event with Hf model ages varying between 2.99 and $3.20 \mathrm{Ga}$.

The $\mathrm{U}-\mathrm{Pb}$ ages and $\mathrm{Hf}$ isotope data of psammopelite and quartzite samples, obtained in this study, show broad overlap. Zircon grains with ages ranging between 2.7 and $2.8 \mathrm{Ga}$ in the Itna sample were characterized by juvenile crustal signature ( $\varepsilon \mathrm{Hf}$ value ranging between +0.2 and +2 ), whereas the $2.5 \mathrm{Ga}$ zircon population was characterized by evolved Hf-isotope value $(\varepsilon \mathrm{Hf}-3.9$ to -5.1 ), indicating signature of reworked older crust or metamorphism.

\section{Discussion}

Earlier workers have considered that the Sargur Group rocks are all older than $3 \mathrm{Ga}$ (refs 20,29). $\mathrm{U}-\mathrm{Pb}$ and $\mathrm{Lu}-\mathrm{Hf}-\mathrm{Yb}$ isotopic data presented here show that even the older population zircons in the quartzites and psammopelites of Sargur type area were derived from a juvenile magmatic crustal source whose age was in the range 2.7-2.8 Ga. Lu-Hf isotopic systematics for the older population zircons in the Sargur Group samples, also suggest an age younger than $3 \mathrm{Ga}$. Our data, therefore, do not support the view that the Sargur Group supracrustals, as a whole, were derived from $>3 \mathrm{Ga}^{\text {crust }^{29}}$.

The ages reported here overlap the SHRIMP $\mathrm{U}-\mathrm{Pb}$ zircon ages $(2.72 \mathrm{Ga})$ of felsic volcanic rocks of the Bababudan Group of the Dharwar Supergroup reported by Trendall et $a l^{24}$. Lu-Hf isotopic systematics of the younger $(2.5 \mathrm{Ga})$ population of zircons in this study are characterized by evolved Hf-isotope value ( $\varepsilon \mathrm{Hf}-3.9$ to -5.1). ${ }^{176} \mathrm{Hf}-{ }^{177} \mathrm{Hf}$ of the younger population apparently show relatively minor variation and are identical to the older zircons within the error limits (Figure 5). This suggests that the observed array can be interpreted to reflect resetting of the $\mathrm{U}-\mathrm{Pb}$ systematics, while preserving the initial ${ }^{176} \mathrm{Hf}-{ }^{177} \mathrm{Hf}$ incorporated during magmatic crystallization. However, there is a gap of almost 150-200 million years between the older and younger age populations zircons. Therefore, resetting during magmatic crystallization as the cause for younger $\mathrm{U}-\mathrm{Pb}$ ages is a difficult proposition. This resetting may have been caused by later metamorphism that has affected the rock formations of the area. The possibility that the $\mathrm{U}-\mathrm{Pb}$ isotope systematics in some of the older detrital zircons might have been reset during the reported $2.5 \mathrm{Ga}$ granulite metamorphism has been suggested by some workers ${ }^{33,39}$. In the ${ }^{176} \mathrm{Hf}-$ ${ }^{177} \mathrm{Hf}_{\text {int }}$ versus apparent $\mathrm{Pb}-\mathrm{Pb}$ age (Figure 4) diagram, similar ${ }^{176} \mathrm{Hf}-{ }^{177} \mathrm{Hf}$ ratio suggested that the studied zircon ages could have been reset during subsequent geological events. However, magmatic and metamorphic zircon domains maintained their primary hafnium isotopic signatures even during high-grade polymetamorphic con- ditions ${ }^{16,19}$. The horizontal arrays of the ${ }^{176} \mathrm{Hf}-{ }^{177} \mathrm{Hf}$ isotope data can be interpreted to result from post crystallization metamorphic alteration, which caused single or multiple $\mathrm{Pb}$-loss events but did not change the primary ${ }^{176} \mathrm{Hf}-{ }^{177} \mathrm{Hf}$ (see refs 16, 19).

As the type area of Sargur Group is in the amphibolite to granulite transition zone in southern India, the possibility that younger age population of zircons represents metamorphic resetting of ages ca $2.5 \mathrm{Ga}$ cannot be ruled out. However, the older core ages ranging between 2.66 and $2.80 \mathrm{Ga}$ have not undergone resetting. The $\mathrm{Th} / \mathrm{U}$ ratio of the younger rims were much lower than the unaltered cores. The results obtained in this study suggest that the 2.66-2.81 Ga juvenile magmatic zircons, found as detritus in Sargur Group sediments, were subjected to metamorphic resetting at ca. $2.50 \mathrm{Ga}$. Based on $\mathrm{Pb}-\mathrm{Pb}$ isotopic study of marbles from the type area of Sargur Group, Sarangi et al. $^{32}$ also did not obtain evidence of metamorphism older than $2.5 \mathrm{Ga}$; the age of metamorphism was the same as recorded by Russel et al. $^{40}$ in the marbles of Dharwar Supergroup. Hokada et al. ${ }^{27}$ have reported $3.08 \mathrm{Ga}$ monazite age as probable for metamorphism of the Sargur Group. Our zircon age data do not support this view. ${ }^{176} \mathrm{Hf}-{ }^{177} \mathrm{Hf}_{\text {int }}$ versus apparent $\mathrm{Pb}-\mathrm{Pb}$ ages (Figure 4) suggests that all zircons were formed during the same geological event, but were subjected to $\mathrm{Pb}$-loss or resetting of different intensities. It is possible that in the Sargur area there are supracrustal enclaves in gneisses, some of which are older than $3 \mathrm{Ga}$, as exemplified by quartzites studied by Lancaster et $a l .{ }^{29}$, and others younger than $3 \mathrm{Ga}$. While the latter may represent torn/detached remnants of Dharwar granite-greenstone succession (Dharwar Supergroup), the former may be of rocks predating the Bababudan Group of the Dharwar Supergroup. Sargur Group is, therefore, a complex of rocks of different ages, a view conceded to by Ramakrishnan $^{28}$.

The present zircon $\mathrm{U}-\mathrm{Pb}$ geochronological study of the high-grade metamorphosed supracrustal rocks of Sargur Group from the Dharwar Craton shows that in the Archaean gneiss-granulite terrains, there can be inclusions of supracrustal rocks of greenstone belts in the deeper crust. It is possible that the Sargur Group is a complex of rocks of more than one age, some predating the Dharwar Supergroup and others of the same age as those of Dharwar Supergroup. Therefore, the metasedimentary enclaves in the type area of Sargur Group have no independent stratigraphic status. They are part of gneiss-supracrustal complex of different ages and antiquities. Although the new geochronological results obtained in this study are limited, they underscore the need for further zircon geochronological and Hf-isotopic study to resolve the complex stratigraphic relationships of highgrade supracrustal rocks in the gneiss-granulite terrains in relation to the low-grade supracrustal rocks in the Dharwar greenstone belts. 


\section{Conclusion}

The results of combined $\mathrm{U}-\mathrm{Pb}$ and $\mathrm{Lu}-\mathrm{Hf}$ isotopic studies on the zircons of Sargur supracrustal rocks from the type area may be summarized as follows: (i) The zircons belong two age populations of concordant $\mathrm{U}-\mathrm{Pb}$ ages; an older population with ages ranging between 2.66 and $2.81 \mathrm{Ga}$, and a younger population $\sim 2.5 \mathrm{Ga}$. (ii) $\mathrm{Lu}-\mathrm{Hf}$ isotopic systematics of the zircons provides evidence that 2.66-2.81 Ga juvenile rock components also supplied sediments to the protoliths of Sargur supracrustals. (iii) Regional metamorphism at $\sim 2.5 \mathrm{Ga}$ affected the $\mathrm{U}-\mathrm{Pb}$ systematics in some of the zircons in the Sargur Group metasediments. (iv) The metasedimentary enclaves in the type area of Sargur Group, as they are composed of sediments older as well as younger than $3 \mathrm{Ga}$, may not have an independent stratigraphic status.

1. Condie, K. C., Archean Greenstone Belts, Elsevier, 1981, p. 434

2. Windley, B. F. and Bridgwater, D., The evolution of Archean lowand high-grade terrains. Geol. Soc. Aust. Spec. Publ., 1971, 3, 33 46.

3. Glikson, A. and Lambert, I. B., Vertical zonation and petrogenesis of early Precambrian crust in Western Australia. Tectonophy, 1976, 30, 55-59.

4. Shackleton, R. M., Shallow and deep-level exposures of Archean crust in India and Africa. In The Early History of the Earth (ed. Windley, B. F.), John Wiley \& Sons, New York, 1976, pp. $317-$ 333 .

5. Goodwin, A. M., Archean basin-craton complexes and the growth of Precambrian shields. Can. J. Earth Sci., 1977, 14, 2737-2759.

6. Naqvi, S. M., Divakara Rao, V. and Narain, H., The primitive crust: evidence from the Indian shield. Precambrian Res., 1978, 6, 323-345.

7. Srinivasan, R., Present status of the Sargur Group of the Archean Dharwar craton, south India. Indian J. Geol., 1988, 60, 57-72.

8. Srinivasan, R. and Naha, K., Apropos of the Sargur Group in the Early Precambrian Dharwar tectonic province. In Recent Researches in Geology and Geophysics of the Precambrians (ed. Saha, A. K.), Hindustan Publishing Corporation, New Delhi, 1996, vol. 16 , pp. $43-48$.

9. Windley, B. F., Crustal development in the Precambrian. Philos. Trans. R. Soc. London Ser. A, 1973, 273, 321-341.

10. Peucat, J.-J., Mahabaleshwar, B. and Jayananda, M., Age of younger tonalitic magmatism and granulitic metamorphism in the South India transition zone (Krishnagiri area); comparison with older Peninsular gneisses from the Gorur-Hassan area. J. Metamorphic. Geol., 1993, 11, 879-888.

11. Nutman, A. P., Chadwick, B., Ramakrishnan, M. and Viswanatha, M. N., SHRIMP $\mathrm{U}-\mathrm{Pb}$ ages of detrital zircons in Sargur supracrustal rocks in western Karnataka. J. Geol. Soc. India, 1992, 39, 367-374.

12. Collins, A. S., Kröner, A., Fitzsimon, I. C. W. and Razakamanana, T., Detrital footprint of the Mozambique Ocean: U-Pb SHRIMP and $\mathrm{Pb}$ evaporation zircon geochronology of metasedimentary gneisses in Eastern Madagascar. Tectonophysics, 2003, 375, 7799.

13. Santosh, M., Collins, A. S., Morimoto, T. and Yokoyama, K., Depositional constraints and age of metamorphism in southern India: $\mathrm{U}-\mathrm{Pb}$ chemical (EPMA) and isotopic (SIMS) ages from the Trivandrum Block. Geol. Mag., 2005, 142(3), 255-268.

14. Gerdes, A. and Zeh, A., Combined $\mathrm{U}-\mathrm{Pb}$ and $\mathrm{Hf}$ isotope LA(MC)ICPMS analyses of detrital zircons: comparison with
SHRIMP and new constraints for the provenance and age of Armorican metasediment in Central Germany. Earth Planet. Sci. Lett., 2006, 249, 47-61.

15. Zeh, A. and Gerdes, A., U-Pb and $\mathrm{Hf}$ isotope record of detrital zircons from gold-bearing sediments of the Pietersburg Greenstone Belt (South Africa) - is there a common provenance with the Witwatersrand Basin. Precambrian Res., 2012, 204-205, 46-56.

16. Gerdes, A. and Zeh, A., Zircon formation versus zircon alteration-new insights from combined $\mathrm{U}-\mathrm{Pb}$ and $\mathrm{Lu}-\mathrm{Hf}$ in situ LA-ICP-MS analyses, and consequences for the interpretation of Archean zircon from the Central Zone of the Limpopo Belt. Chem. Geol., 2009, 261(3-4), 230-243.

17. Yoshida, M., Geochronological data evaluation: implications for the Proterozoic tectonics of East Gondwana. Gondwana Res., 2007, 12(3), 228-241.

18. Vervoort, J. D. and Blichert-Toft, J., Evolution of the depleted mantle: Hf isotope evidence from juvenile rocks through time. Geochim. Cosmochim. Acta, 1999, 63(3/4), 533-556.

19. Zeh, A., Gerdes, A. and Barton Jr, J. M., Archean accretion and crustal evolution of the Kalahari Craton - the zircon age and $\mathrm{Hf}$ isotope record of granitic rocks from Barberton/Swaziland to the Francistown Arc. J. Petrol., 2009, 50, 933-966.

20. Swami Nath, J. and Ramakrishnan, M., Early Precambrian supracrustals of southern Karnataka. Mem. Geol. Surv. India, 1981, 112, 308.

21. Ramakrishnan, M. and Vaidyanathan, R., Geology of India; Vol. 1, Geological Society of India, Bangalore, India, 2008, p. 556.

22. Jayananda, M., Kano, T., Peucat, J. J. and Channabasappa, S., $3.5 \mathrm{Ga}$. komatiite volcanism in the western Dharwar Craton, southern India: constraints from $\mathrm{Nd}$ isotopes and whole-rock geochemistry. Precambrian Res., 2008, 162, 160-179.

23. Maya, J. M., Bhutani, R., Balakrishnan, S. and Rajee Sandhya, S., Petrogenesis of $3.15 \mathrm{Ga}$ old Banasandra komatiites from the Dharwar craton, India: implications for early mantle heterogeneity. Geosci. Front., 2016; http://dx.doi.org/10.1016/j.gsf.2016.03.007.

24. Trendall, A. F., De Laeter, J. R., Nelson, D. R. and Bhaskar Rao, Y. J., Further zircon $\mathrm{U}-\mathrm{Pb}$ age of the Daginkatte Formation, Dharwar Supergroup, Karnataka craton. J. Geol. Soc. India, 1997, 50, 25-30.

25. Jayananda, M., Moyen, J.-F., Martin, H., Peucat, J.-J., Auvray, B. and Mahabaleswar, B., Late Archaean (2550-2520 Ma) juvenile magmatism in the Eastern Dharwar craton, southern India: constraints from geochronology, $\mathrm{Nd}-\mathrm{Sr}$ isotopes and whole rock geochemistry. Precambrian Res., 2000, 99, 225-254.

26. Jayananda, M., Peucat, J.-J., Chardon, D., Krishna Rao, B., Fanning, C. M. and Corfu, F., Neoarchean greenstone volcanism and continental growth. Dharwar craton, south India: constraints from $\mathrm{SIMS} \mathrm{U}-\mathrm{Pb}$ zircon geochronology and $\mathrm{Nd}$ isotopes. Precambrian Res., 2013, 227, 55-76.

27. Hokada, T., Horie, K., Satish-Kumar, M., Ueno, Y., Nasheeth, A., Mishima, K. and Shiraishi, K., An appraisal of Archaean supracrustal sequences in Chitradurga Schist Belt, Western Dharwar Craton, southern India. Precambrian Res., 2013, 227, 99-119.

28. Ramakrishnan, M., Stratigraphic evolution of Dharwar craton. Geokarnataka, Mysore Geological Department Centenary Volume, Karnataka Geologists Association, Bangalore, India, 1994, pp. 6-35.

29. Lancaster, P. J., Dey, S., Storey, C. D., Mitra, A. and Bhunia, R. K., Contrasting crustal evolution processes in the Dharwar craton: insights from detrital zircon $\mathrm{U}-\mathrm{Pb}$ and $\mathrm{Hf}$ isotopes. Gondwana Res., 2015, 28(4), 1361-1372.

30. Buhl, D., Grauert, B. and Raith, M., U-Pb zircon dating of Archaean rocks from south Indian craton: results from amphibolitegranulite facies transition zone at Kabal quarry, southern Karnataka. Fortschritt. Mineral., 1983, 61, 43-45.

31. Ramakrishnan, M., VenkataDasu, S. P. and Kröner, A., Middle Archaean age of Sargur Group by single grain zircon dating and 
geochemical evidence for clastic origin of metaquartzite from J.C. Pura greenstone belt, Karnataka. J. Geol. Soc. India, 1994, 44, 605-616.

32. Sarangi, S., Gopalan, K. and Srinivasan, R., Small-scale sampling for $\mathrm{Pb}-\mathrm{Pb}$ dating of marbles: example from the Sargur supracrustal rocks, Dharwar Craton, South India. Precambrian Res., 2007, 152, 83-91

33. Peucat, J.-J., Jayananda, M., Chardon, D., Capdevilla, R., Fanning, C. M. and Paquette, J.-L., The lower crust of the Dharwar craton, southern India: patchwork of Archean granulitic domains. Precambrian Res., 2013, 227, 4-28.

34. Srikantappa, C., Raith, M. and Ackermand, D., High-grade regional metamorphism of ultramafic and mafic rocks from the Archean Sargur terrane, Karnataka, South India. Precambrian Res., 1985, 30, 189-219.

35. Janardhan, A. S., Ramachandra, H. M. and Ravindra Kumar, G. R., Structural history of Sargur supracrustals and associated gneisses south-west of Mysore, Karnataka. J. Geol. Soc. India, 1979, 20, 61-72.

36. Viswanatha, M. N. and Ramakrishnan, M., Sargur and allied belts. Mem. Geol. Surv. India, 1981, 112, 41-59.

37. Arndt, N. T. and Goldstein, S. L., Use and abuse of crustformation ages. Geology, 1987, 15, 893-895.

38. Kemp, A. I. S., Hawkesworth, C. J., Paterson, B. A. and Kinny, P. D., Episodic growth of the Gondwana supercontinent from hafnium and oxygen isotopes in zircon. Nature, 2006, 439, 580-583.

39. Raith, M. M., Srikantappa, C., Buhl, D. K. and Köhler, H., The Nilgiri Enderbites, South India: nature and age constraints on pro- tolith formation, high-grade metamorphism and cooling history. Precambrian Res., 1999, 98, 129-150.

40. Russel, J., Chadwick, B., Krishna Rao, B. and Vasudev, V. N., Whole-rock $\mathrm{Pb} / \mathrm{Pb}$ ages of Late Archaean limestones, Karnataka, India. Precambrian Res., 1996, 78, 261-272.

41. Chardon, D., Jayananda, M., Chetty, T. R. K. and Peucat, J. J., Precambrian continental strain and shear zone patterns: South Indian case. J. Geophys. Res., 2008, 113 (B08402), 1-16.

42. Stacey, J. S. and Kramers, J. D., Approximation of terrestrial lead isotope evolution by a two-stage model. Earth Planet. Sci. Lett., 1975, 26, 207-221.

43. Bouvier, A., Vervoort, J. D. and Patchett, P. J., The Lu-Hf and Sm-Nd isotopic composition of CHUR: constraints from unequilibrated chondrites and implications for the bulk composition of terrestrial planets. Earth Planet. Sci. Lett., 2008, 273, 48-57.

ACKNOWLEDGEMENTS. M.B. analysed the samples during a visit to the University of Mainz, supported by the University of Mainz Geocycles Project (courtesy: Prof. Stephen Foley). We thank the two anonymous reviewers for constructive comments.

Received 22 March 2017; revised accepted 21 September 2017

doi: $10.18520 / \mathrm{cs} / \mathrm{v} 113 / \mathrm{i07/1394-1402}$ 